\title{
Brownification and its consequences for the ecosystems of Lake Onego and Vygozerskoe reservoir under influence of climatic and anthropogenic factors
}

LIMNOLOGY FRESHWATER

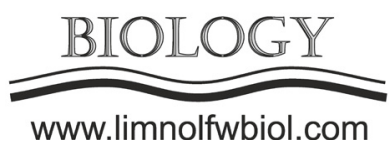

\author{
Kalinkina N.M.*, Tekanova E.V., Ryzhakov A.V.
}

Northern Water Problems Institute of the Karelian Research Centre of the Russian Academy of Sciences Aleksander Nevsky Str., 50, Petrozavodsk, Republic of Karelia,185030, Russia

\begin{abstract}
The consequences of climatic changes in the conditions of anthropogenic load weakening are considered for the ecosystems of the largest lake-reservoirs in the northwestern region of Russia (Lake Onego and Vygozerskoe reservoir). The catchment areas of these water bodies are rich in bogs. The rise of the humic substances flow became a new regulatory factor in the functioning of these reservoirs due to an increase in winter river flow in conditions of climate warming. Geochemical indicators of the increasing influence of the catchment area on the water chemical composition in the studied lakes were a simultaneous increase in the color of water (brownification), the concentration of iron and carbon dioxide, and a decrease in $\mathrm{pH}$. The accumulation of iron at the bottom of Lake Onego caused inhibition of deep-water benthic communities. The state of benthos of Vygozerskoe reservoir is associated with the consequences of influence of pulp and paper mill wastewater, the highest toxicity of which was observed in the previous period.
\end{abstract}

Keywords: Lake Onego, Vygozerskoe reservoir, climatic changes, allochthonous substances, benthos.

Lake Onego and Vygozerskoe reservoir are parts of the White Sea-Baltic Canal, the important waterway of the northwestern region of Russia. In recent decades, these reservoirs have been experiencing an increased influence of the catchment area, which is associated with climate warming in Karelia. Since the 1990s, the frequency of mild winters has increased in Karelia, which has led to an increase in the winter flow of rivers and an increase in the influence of bogged catchment areas on lake ecosystems. So, for the period 1990-2016, the intake of river humus substances and associated iron and phosphorus with the river waters into the Petrozavodsk Bay of Lake Onego increased (Filatov et al., 2018). An increase in the runoff of allochthonous substances caused the rise of the color of water in the Bay in the spring (by 40\%), a 3.5-fold increase in the total iron content, a 3-fold increase in the concentration of carbon dioxide (Kalinkina et al., 2019).

Similar to Lake Onego, the consequences of increasing runoff of allochthonous substances are observed in Vygozerskoe reservoir. For about 20 years, the Vygozerskoe reservoir is at the stage of reoligotrophization due to a decrease in the supply of phosphorus with wastewater from the pulp and paper mill (Tekanova et al., 2011). During decline of anthropogenic load, the increase in the flow of allochthonous substances became one of the main regulatory factors. For the period 1992-2017 the statistical analysis of changes in the concentration of $\mathrm{CO}_{2}$ and total iron in the water of Vygozerskoe reservoir was made. It turned out that these indicators are significantly increasing, especially a sharp increase has been observed since 2007. Significant values of Spearman's correlation coefficients between the year of observation and the iron content $(0.61)$, the year and the concentration of $\mathrm{CO}_{2}(0.58)$, and concentrations of $\mathrm{CO}_{2}$ and iron (0.57) testify to a systematic change in the chemical composition of Vygozerskoe reservoir water. In 2017 the significant increasing of color of water was found in the southern part of Vygozerskoe reservoir. Taking into account the high color of the tributaries, the observed changes indicate an increase in the effect of river runoff on a water body in the last decade. The entry of iron into the water in the Vygozerskoe reservoir is also associated with its release from bottom sediments (Belkina, 2015). An increase in the runoff of iron led to its accumulation at the bottom. In this regard, the influence of the catchment area affected the condition of the deep-water benthos of Lake Onego to the greatest degree. Since the 2000s, the number of benthos in the Petrozavodsk Bay has decreased 7 times, biomass - 6 times, production - 4-6 times. The state of benthos of Vygozerskoe reservoir is determined, first of all, by the influence of the anthropogenic factor, which

*Corresponding author.

E-mail address: cerioda@mail.ru (N.M. Kalinkina)

(C) Author(s) 2020. This work is distributed under the Creative Commons Attribution 4.0 License. 
caused its sharp inhibition as a result of the pulp and paper mill wastewater discharge in previous period.

Thus, beginning the 1990s, in conditions of climate change, a strong new factor, the rise of allochthonous substances flow, influences on the ecosystems Lake Onego and Vygozerskoe reservoir.

\section{Acknowledgments}

The study was conducted in accordance with a state assignment given to the Karelian Research Center of the Russian Academy of Sciences (Northern Water Problems Institute, KRC, RAS).

\section{References}

Belkina N.A. 2015. Bottom sediments of Vygozerskoe reservoir. In: Filatov N.N., Kalinkina N.M., Kulikova T.P. et al. (Eds.), Krupneyshiye ozera - vodokhranilishcha Severo-Zapada
YeTR: sovremennoye sostoyaniye i izmeneniya ekosistem pri klimaticheskikh i antropogennykh vozdeystviyakh [The largest lakes-reservoirs in the northwest of European part of Russia: current state and changes in ecosystems under climatic and anthropogenic influences]. Petrozavodsk, pp. 247-256. (in Russian)

Filatov N.N., Kalinkina N.M., Tekanova E.V. 2018. Modern changes in the ecosystem of Lake Onego with climate warming. Limnology and Freshwater Biology 1: 15-17. DOI: 10.31951/2658-3518-2018-A-1-15

Kalinkina N.M., Tekanova E.V., Sabylina A.V. et al. 2019. Changes in the hydrochemical regime of Onego Lake since the early 1990s. Izvestiya Rossiiskoy Akademii Nauk. Seriya Geograficheskaya [Proceedings of the RAS. Geographical Series] 1: 62-72. DOI: 10.31857/S2587-55662019162-72 (in Russian)

Tekanova E.V., Lozovik P.A., Kalinkina N.M. et al. 2011. Current state and transformation of the northern part of the Vygozerskoe reservoir. Trudy Karel'skogo Nauchnogo Tsentra Rossiyskoy Akademii Nauk [Transactions of the Karelian Research Center of the Russian Academy of Science] 4: 50-56. (in Russian) 